\title{
ESCOLA, CATEQUESE E FORMAÇÃO DE PROFESSORES: OS MISSIONÁRIOS ORIONITAS E A CATOLICIZAÇÃO DO ANTIGO EXTREMO NORTE DE GOIÁS POR INTERMÉDIO DA EDUCAÇÃO, 1950-1960 ${ }^{1}$
}

\author{
Raylinn Barros da Silva* \\ lattes.cnpq.br/5908615849463190
}

Resumo: O objetivo deste estudo é refletir o processo de catolicização do antigo extremo norte de Goiás, por intermédio da educação, processo desencadeado pelos missionários católicos orionitas nas décadas de 1950 e 1960. Este estudo é resultado de uma pesquisa bibliográfica e as fontes analisadas são as obras de memória dos próprios missionários. A justificativa para este estudo é a necessidade de historicizar essas fontes, o que contribui para a compreensão de parte da história religiosa da região, atual norte do Tocantins.

Palavras- chave: Orionitas; Goiás; Educação; Escola; Catequese.

\section{SCHOOL, CATECHESIS AND TEACHER FORMATION: THE ORIONITE MISSIONARIES AND THE CATHOLICIZATION OF THE OLD FAR NORTHERN GOIÁS THROUGH EDUCATION, 1950-1960}

\begin{abstract}
The aim of this study is to reflect the process of catholicization of the ancient far northern of Goiás, through education, a process triggered by the Orionite Catholic missionaries in the 1950s and 1960s. This study is the result of a literature search and the sources analyzed were pieces of memory of the own missionaries. The justification for this study is the need to historicize these sources, which contributes to the understanding of part of the religious history of the region, current northern Tocantins.
\end{abstract}

Keywords: Orionite, Goiás; Education; School; Catechism.

\footnotetext{
${ }^{1}$ Pesquisa com financiamento do CNPq - Conselho Nacional de Desenvolvimento Científico e Tecnológico.

${ }^{*}$ Doutorando em História pela Universidade Federal de Goiás (Brasil). Contato: raylinn barros@hotmail.com.
} 


\section{Revista de História e}

Historiografia da Educação

\section{Introdução}

Este estudo tem como objetivo refletir o que pode ter sido o processo de catolicização da região do antigo extremo norte de Goiás, por intermédio da educação, processo desencadeado pelos missionários católicos orionitas nas décadas de 1950 e 1960. Esta análise é resultado de pesquisa bibliográfica, as fontes são obras de memória dos próprios missionários orionitas ${ }^{2}$. Os principais missionários deixaram registrados momentos importantes das duas primeiras décadas da missão em solo goiano, esses registros compõe um quadro que, aos olhos dos orionitas, contam parte da história da região objeto deste estudo.

Essas obras receberam tratamento crítico a partir de estudos no campo da história cultural. A justificativa para este estudo é a necessidade de historicizar essas fontes, o que contribui para a compreensão de parte da história da região, através da hipótese de que educação e religião podem ter sido associadas como instrumento de catolicização do antigo extremo norte de Goiás, região do atual norte do Tocantins.

Os missionários orionitas estabeleceram-se nesse espaço e atuaram em três frentes: educação, saúde e construção de templos católicos. Especificamente nesta reflexão, analisa-se a atuação desses missionários no campo educacional, pois na região, ao que parece, não só implantaram as primeiras escolas, mas, como será possível perceber, utilizaram a educação como instrumento de catolicização da região.

Sobre o extremo norte de Goiás que foi o espaço de atuação dos missionários orionitas, é onde na atualidade é denominado norte tocantinense. Essa região, à época, tinha na antiga Boa Vista, atualmente a cidade de Tocantinópolis, seu principal centro urbano,

\footnotetext{
2 Pesquisa desenvolvida com apoio do CNPq - Conselho Nacional de Desenvolvimento Científico e Tecnológico.
} 


\section{Revista de História e}

\section{Historiografia da Educação}

político e religioso. Tocantinópolis era considerada estratégica por vários motivos: estava localizada nas margens do Rio Tocantins; fazia divisa com o Maranhão e ainda pela posição geográfica, mais ao norte, estava estrategicamente situada no extremo norte de Goiás na época, localizada entre Maranhão e Pará.

No que se refere ao aspecto religioso, antes da chegada dos missionários orionitas, alguns religiosos católicos já haviam visitado a região do antigo extremo norte goiano, antes mesmo da presença do famoso padre João Lima3. Assim, do ponto de vista da religião católica, antes da chegada dos primeiros missionários orionitas em 1952, a região - com exceção de Boa Vista, atual Tocantinópolis, única paróquia católica4 - era "assistida" do ponto de vista religioso, vez ou outra, quando da passagem de missões religiosas. Primeiro, os capuchinhos no final do século XIX e, no início do XX, os dominicanos (CAIXETA, 2014).

Nesse sentido, como será possível perceber neste estudo, a partir do início da década de 1950 e durante toda a década seguinte, os anos 1960, os orionitas se fixaram na região. Nela construíram as primeiras escolas e, por intermédio dessa atuação no campo educacional, promoveram a catolicização da região. Ao chegarem ao extremo norte goiano, como diagnosticaram a situação da região do ponto de vista da educação? Essas são algumas questões que se refletirá a seguir.

3 Considera-se esse sacerdote como pessoa "famosa" devido a sua atuação e influência tanto no campo religioso quanto no cenário político de Boa Vista à época, primeiras décadas do século XX. Mais informações sobre esse sacerdote católico, consultar: O Coronelismo no extremo norte de Goiás: o Padre João e as três revoluções de Boa Vista de autoria de Luís Palacín ou ainda, Boa Vista do Padre João: Tocantinópolis, Goiás, de autoria de Aldenora Correia.

4 Paróquia Nossa Senhora da Consolação. Até o ano de 1954 pertenceu à Diocese de Porto Nacional, depois desse ano, passou para a administração dos orionitas. 


\section{Revista de História e}

\section{Historiogratia da Educação}

\section{Diagnóstico dos orionitas sobre a educação na região: "grande campo que estava descoberto"}

Como estava o extremo norte goiano no quesito educação quando da chegada dos missionários orionitas? Cesare Lelli, orionita italiano, diagnosticou a realidade da região do ponto de vista da educação no início da década de 1950 quando escreveu:

Quanto ao setor educação, ninguém falava ou procurava-se, bem longe de pensar no grande campo que estava descoberto. Ao chegar aqui o problema da educação, foi um dos primeiros com o qual os padres de Dom Orione defrontaram-se. Entenderam eles que, evangelizar sem instruir aquele povo não daria resultado. Assim o binômio evangelização e educação foi posto como meta prioritária. Ao lado de cada igreja em construção eram também levantadas as paredes para uma escola orionita (LELLI, 1979, p.34-35).

Como se percebe no registro de Lelli, a educação na região se converteu em um dos principais problemas encontrados pelos missionários orionitas. Ele relatou que não daria muito resultado evangelizar o povo sem que a instrução educacional não fosse também administrada junto com os ensinamentos da religião católica. Ele muito claramente escreveu que a educação junto com a evangelização católica foi colocada pelos missionários orionitas como prioridade absoluta e que a cada igreja que foi construída, ao lado era de igual forma construída uma escola orionita.

Observa-se na narrativa do missionário Lelli, quando os orionitas chegaram na região, a educação do lugar se transformou em uma das maiores preocupações para os missionários. Mas por que a educação preocupou tanto os missionários? Sobre essa problemática, José Mateus do Nascimento, ao refletir sobre o papel da Igreja Católica na formação das práticas culturais brasileiras, quando o debate gira em torno da educação, reflete: 


\section{Revista de História e}

Historiografia da Educação

Desde a Colônia, os princípios pedagógicos da Igreja Católica estão presentes de forma hegemônica na educação brasileira. Essa influência se estende durante a construção do pensamento educacional brasileiro e nas práticas estabelecidas (NASCIMENTO, 2006, p.206).

Como se observa a partir da análise de Nascimento, desde a formação do Brasil, a Igreja Católica se fez presente, segundo ele, com seus "princípios pedagógicos”. Ou seja, a educação sempre foi uma preocupação e estratégia da Igreja no país. Com os missionários orionitas no antigo extremo norte goiano essa preocupação ficou também evidente.

É importante observar que em duas cidades da região já existiam escolas. Uma unidade escolar na cidade de Tocantinópolis, de propriedade do estado, e outra em Filadélfia, de propriedade dos protestantes batistas. Sobre a unidade escolar de Tocantinópolis, sede da missão orionita, o missionário Quinto Tonini, escreveu:

Entrou na escola, grupo de crianças, sentadas sobre restos de bancos, outras sobre cadeiras rudimentares trazidas das próprias casas, outras em pé ou agachadas, com a papelada nas mãos, passavam duas ou três horas ao dia, em local úmido e sujo, voltando depois para casa, sem haver entendido o motivo daquelas três horas de tortura. A professora, que no máximo teria feito o quarto ano primário, perdia mais tempo em pedir silêncio aos impenitentes do que em ensiná-los (TONINI, 1996, p.11).

Observam-se, a partir de Tonini, algumas questões: o missionário fez uma crítica à estrutura física da escola, apontou a deficiência da unidade escolar. Ele registrou que as crianças passavam horas sem entender a "tortura". Ele acreditava que a professora só deveria possuir as séries iniciais e que perdia mais tempo pedindo silêncio do que ensinando os alunos. 


\section{Revista de História e}

\section{Historiografia da Educação}

Atesta-se que Tonini não registrou nada de interessante na educação administrada na escola de Tocantinópolis. Ao que parece, poderia mesmo a referida escola não possuir estrutura. Mas acredita-se que a observações de Tonini visou principalmente, desqualificar a educação administrada na escola.

É perceptível no registro de Tonini a preocupação com a educação que estava sendo ministrada em Tocantinópolis, sede da missão orionita. Mas por que o missionário estava preocupado com a formação educacional das pessoas que compunham a sociedade de Tocantinópolis e região? Havia outro interesse por trás da atuação dos orionitas na educação? Sobre essas questões, Riolando Azzi infere que a Igreja Católica no Brasil desde a colônia até os dias atuais: "O ensino ministrado nas aulas não tinha como finalidade específica proporcionar um maior conhecimento do mundo, mas era visto principalmente como um instrumento de afirmação social e cultural" (AZZI, 2008, p.56).

Conforme se observa a partir de Azzi, é possível que o projeto educacional dos missionários orionitas não estivesse também tão preocupado com um tipo de educação baseada na formação intelectual da sociedade, mas como ele inferiu, desde as práticas existentes no Brasil no período colonial, o desejo era também de um tipo de educação como mecanismo de afirmação sociocultural por parte da própria Igreja.

A partir do registro de Tonini, acredita-se que ele buscou primeiro desqualificar a educação para, depois, legitimar o projeto dos orionitas, as ações e o tipo de educação que eles implantariam no extremo norte goiano nas décadas de 1950 e 1960. Os missionários visitavam outras escolas da região, conforme Tonini registrou:

Depois de alguns dias, entre outras pequenas anotações: pediremos ao Padre provincial que mande imediatamente $o$ Padre Tonini (Filadélfia); o Padre Tiveron (Itaguatins). Seguiam esboços aos sacerdotes de horário para o catecismo 


\section{Revista de História e}

Historiografia da Educação

dominical e uma orientação pedagógica para ser aplicada nas escolas do estado (TONINI, 1996, p.12).

Os missionários visitavam as escolas públicas da região e lá aplicavam orientações pedagógicas. Como, se a educação pública brasileira desde o advento da república era considerada laica e, portanto, não religiosa? Consegue-se, por hora, estabelecer duas hipóteses: ou no antigo extremo norte goiano na época, década de 1950, não se tinha a ideia da laicidade do estado brasileiro, ou os missionários orionitas despontavam de elevada moral e credibilidade na região a ponto de garantir-lhes penetração nas escolas públicas para atuarem no aspecto religioso nas mesmas.

No registro de Tonini, observa-se que foi solicitada "orientação pedagógica” para as escolas públicas da região. Para além do acesso dos missionários às escolas públicas, resta uma indagação: qual seria essa orientação pedagógica? o catecismo católico? É possível que sim. Sobre a atuação da Igreja Católica na esfera da educação brasileira, Riolando Azzi reflete que "As pessoas eram educadas para essa supremacia do religioso, que perpassava todas as atividades da comunidade. Para quem transgredisse essas normas, haveria o castigo de Deus" (AZZI, 2008, p.50).

Como refletiu Azzi, a Igreja sempre buscou interferir na educação. Para isso, segundo ele, as pessoas eram educadas para a valorização do religioso, ou seja, da religião católica e suas crenças. Quem ousasse transgredir essa prática seria considerada como pecadora e poderia inclusive receber o castigo do céu.

Como se pode perceber ainda no registro de Tonini, os missionários visitavam as escolas públicas. De certa forma, o que faz acreditar que eles atuavam também como se professores fossem. Ao longo dos tempos, religiosos católicos sempre dispunham da atribuição de serem vistos, também, como espécie de professores. Sobre essa 


\section{Revista de História e}

Historiografia da Educação

associação entre ser religioso e também professor, Thomas Woods reflete:

Os religiosos e monges não apenas fundaram escolas e foram professores. Ao longo dos séculos, os monges e os religiosos sempre foram professores. São João Crisóstomo conta-nos que, já na sua época (347-407), as famílias de Antioquia costumavam confiar a educação dos seus filhos aos religiosos e aos monges. São Bento instruiu os filhos dos nobres romanos. São Bonifácio criou uma escola em cada mosteiro que fundou na Alemanha, e, na Inglaterra, Santo Agostinho de Cantuária e os seus monges abriam escolas onde quer que se fixassem (WOODS, 2008, p.43).

Como se verifica na reflexão de Woods, religiosos católicos sempre buscaram atuar no campo da educação, também como professores. Esse fenômeno não é algo restrito a um lugar ou época. Basta observar que na reflexão de Woods, já se via a Igreja atuando na área educacional desde o século IV. Essa influência da Igreja na educação alcançou o antigo extremo norte goiano com os missionários orionitas.

Como foi possível perceber nessa parte deste estudo, os orionitas ao chegarem à região do antigo extremo norte goiano, no início da década de 1950, diagnosticaram a situação da mesma do ponto de vista da educação. Mas, ao que parece, não ficaram apenas no diagnóstico da realidade da educação, eles decidiram agir nesse campo. O que fizeram, então, a partir desse diagnóstico de que a região era um "grande campo que estava descoberto" como escreveu o missionário orionita Lelli?

A seguir, será possível perceber que os missionários orionitas intensificaram seus trabalhos no campo educacional: decidiram formar professores para atuarem nas escolas da região. Isso mesmo, os missionários orionitas tendo Tonini e Corazza à frente, elaboraram um projeto e colocaram em prática no referido contexto, um curso de 
aperfeiçoamento de professores no âmbito da missão orionita no extremo norte de Goiás.

\section{Os orionitas intensificam ações no campo educacional: formar professores}

Sobre o curso administrado pelos orionitas no sentido de formar e aperfeiçoar professores da região, Tonini escreveu:

No dia 12 de julho daquele ano, os professores iniciavam o curso. Eram nove aulas por dia: quatro pela manhã, quatro à tarde e uma à noite. Ministraram-se aulas de religião, metodologia, didática, pedagogia, educação sanitária, elementos de agrária e trabalhos manuais. Os mestres eram da Universidade de Goiânia, eram todos seguidores do método de D. Bosco e católicos fervorosos. O resultado do curso foi confortador. No dia 28, o curso encerrou-se com uma bonita cerimônia da qual participaram o Governador de Goiás, três Deputados Federais, quatro Estaduais, os prefeitos de vários municípios, além de autoridades de Carolina. No final, fundou-se a "União dos Professores Primários NorteGoiano", uma associação católica de assistência moral e cultural, sob a dependência da missão (TONINI, 1996, p.198200).

Sobre a criação do curso de formação e aperfeiçoamento dos professores do antigo extremo norte goiano, várias observações precisam ser feitas. A princípio, observa-se que entre as disciplinas a serem administradas no curso, a primeira é sobre religião, certamente, a religião católica. Havia a disciplina de educação sanitária, pois os missionários orionitas atuaram além da educação, também área da saúde.

Tonini registrou que o curso foi aplicado por professores de uma universidade sediada na capital, Goiânia e que, destaca ele: todos eram católicos fervorosos, seguidores do método educacional de Dom Bosco, 


\section{Revista de História e}

Historiografia da Educação

sacerdote católico fundador da Congregação Salesiana. Observa-se, então, que os professores que administraram o curso eram ligados ao catolicismo.

Surpreendente verificar que a partir do encerramento do curso, formou-se uma associação de professores, que o próprio Tonini registrou como "associação católica de assistência moral", sob o direcionamento da missão orionita. Ou seja, os professores faziam daquele momento em diante, parte de um grupo que deveria, ao que parece, manter o que havia sido aprendido no curso: uma educação católica para as escolas da região.

Tonini registrou ainda que no encerramento do curso, que ele afirmou ter alcançado êxito, participaram autoridades de Goiás à época. O que nos leva a acreditar que no contexto, a década de 1950, os missionários orionitas despontavam de notoriedade além da região, mas inclusive na capital, Goiânia. Autoridades políticas estavam, nesse sentido, respaldando o trabalho dos missionários orionitas no extremo norte de Goiás.

Ao refletir sobre esse registro de Tonini, não há como não imaginar a natureza da educação proporcionada a partir de então por esses missionários nas escolas públicas do extremo norte goiano. Acredita-se que foi uma educação de base católica e, portanto, proselitista, educação pautada nos ensinamentos da igreja, sob o que os orionitas acreditavam ser o correto, o verdadeiro, o válido para povo da região. Ou seja, uma educação católico-orionita esteve em curso no espaço e contexto histórico analisado neste estudo.

Sobre a atuação dos missionários orionitas no campo da educação na região, Vera Caixeta reflete:

Tanto nos missionários católicos quanto para os protestantes existia uma estreita vinculação entre a prática religiosa e a prática escolar. Organizar igrejas e escolas não era práticas estanques porque para ambos a missão de evangelizar incluía romper com as superstições, ignorância e práticas arcaicas 


\section{Revista de História e}

\section{Historiografia da Educação}

que se acreditavam amplamente enraizadas na sociedade sertaneja. A escola transformou-se em campo de luta (CAIXETA, 2014, p. 172).

Assim como refletiu Caixeta, observa-se como se deu a relação entre os missionários orionitas e as escolas na região: uma estreita vinculação entre ambas. De fato, os orionitas transformaram as escolas da região como apontou Caixeta, em um verdadeiro "campo de batalha". Batalha contra quem? Contra os protestantes em primeiro lugar, depois, contra a "ignorância” dos sertanejos, suas "superstições", práticas e costumes considerados “arcaicos” pelos missionários.

Como se percebe, os interesses dos missionários orionitas em atuarem na esfera da educação não estavam pautados somente na intenção de melhorar a educação da região, mas como observado até aqui, havia um projeto religioso por trás dessa atuação orionita no campo da educação. Por que um projeto religioso? Porque eram os protestantes, no campo da educação, os maiores "inimigos" dos missionários.

Como se verifica nessa orientação dada, em 1952, pelo bispo de Porto Nacional, o dominicano francês, Dom Alano Marie Du Noday à Tonini:

Abra logo escolas para enfrentar os protestantes, faça ainda grandes catecismos, organize associações e outras coisas que julgar necessário. Você é sacerdote, deve cortar as estradas aos inimigos de Cristo, com prudência, mas oportuna e decisivamente (TONINI, 1996, p.20).

A partir da orientação do bispo à Tonini, observa-se que existia um empecilho à catolicização do povo no contexto: os protestantes. E o caminho estava colocado: abrir escolas para enfrentar os "inimigos". De fato, Tonini e os missionários deixaram de atuar somente nas escolas públicas e começaram a abrir várias escolas orionitas na região. $\mathrm{O}$ trabalho desenvolvido até então, de formar professores para atuarem 


\section{Revista de História e}

\section{Historiografia da Educação}

nas escolas públicas não respondia mais aos anseios dos missionários orionitas.

O trabalho de levar o catolicismo às escolas do antigo extremo norte goiano não ficou apenas no âmbito das pouquíssimas escolas públicas existentes à época, os orionitas abriram escolas em todas as sedes da missão nas décadas de 1950 e 1960, como se poderá verificar a seguir.

\section{Os orionitas decidem fundar escolas: a educação a serviço da religião}

Os missionários orionitas decidiram instalar em todas as sedes da missão escolas paroquiais. Importante observar que a estratégia da Igreja de atuar na esfera da educação não é incomum. Sobre essa a atuação da Igreja Católica no Brasil na área da educação, José Mateus do Nascimento reflete:

Por intermédio de práticas educativas, sobretudo com as crianças e jovens, a Igreja Católica fortalecia sua presença no interior do país, principalmente nas comunidades carentes. Ainda que nelas não existisse um templo católico erguido, inúmeras "igrejas vivas" haviam sido construídas, verdadeiros núcleos irradiadores de uma religiosidade católica (NASCIMENTO, 2006, p.68-69).

A Igreja Católica se fez presente com suas escolas e suas práticas educativas pelo interior do país, sobretudo nas regiões mais carentes. Segundo Nascimento, a estratégia foi fazer-se presente para a irradiação de uma religiosidade especificamente católica. No caso do extremo norte de Goiás na década de 1950 e 1960, não foi diferente. Nesse sentido, os missionários orionitas fundaram escolas em todas as sedes em que atuavam na região. 


\section{Revista de História e}

\section{Historiografia da Educação}

Sobre a expansão da atuação orionita em todas as sedes da missão no antigo extremo norte goiano, Tonini escreveu: "Todas as sedes tinham suas escolas paroquiais" (TONINI, 1996, p.103). As duas escolas orionitas mais antigas foram fundadas na metade da década de 1950.

Primeiro, no ano de 1954, uma unidade escolar em Tocantinópolis, sede da missão orionita, que na sua fundação foi denominado Ginásio do Norte Goiano, depois transformado em Colégio Dom Oriones.

Na sequência, por ordem de antiguidade, em 1955 foi fundada uma unidade escolar em Araguaína, a Escola Sagrado Coração de Jesus, depois chamada de Escola Paroquial Sagrado Coração de Jesus. Oito anos depois, em 1963, na mesma cidade de Araguaína, os orionitas fundaram também o Ginásio Santa Cruz, depois denominado de Colégio Santa Cruz.

Destacam-se essas três escolas orionitas pelo fato que, desde a fundação nas décadas de 1950 e 1960, transformaram-se nas três principais unidades de ensino pertencentes aos missionários orionitas. Outras escolas orionitas foram criadas em outras cidades como Filadélfia, Babaçulândia, Ananás, Araguatins, Itaguatins e Xambioá. Sobre a mais antiga escola orionita, o Ginásio do Norte Goiano em Tocantinópolis, Tonini escreveu:

Surgiu por iniciativa do Prefeito de Tocantinópolis, em colaboração com os sacerdotes de Dom Orione, aos quais foi logo confiada a direção. Em seguida, vendo-se o prefeito impossibilitado de ajudar a instituição, cedeu-a integralmente

\footnotetext{
5 Essa unidade escolar orionita desde a criação é uma escola sem fins lucrativos, de natureza pública. Na atualidade, é um colégio de grande porte em Tocantinópolis, por sinal, o principal estabelecimento de ensino da cidade. Nos anos 1990 foi firmada uma parceria com o governo do Tocantins, a partir de então, professores e demais servidores desse colégio são remunerados pelo poder público estadual. Esse estabelecimento de ensino já chegou a contar com um público de 1.100 alunos, atualmente, tem cerca de 600 alunos matriculados.
} 


\section{Revista de História e}

Historiografia da Educação

à Congregação dos Filhos da Divina Providência. O primeiro diretor foi o Pe. André Alice. Após a morte do Pe. Luiz Bettiol, a direção e as disciplinas mais pesadas passaram para as mãos do Pe. Breviglieri. Em Goiânia e em Belém, o Ginásio sempre gozou fama como um dos mais organizados e eficientes do interior brasileiro (TONINI, 1996, p.226-227).

Como é possível observar, a mais antiga escola orionita da região surgiu de uma parceria com a prefeitura da cidade de Tocantinópolis. Tonini no seu registro não quis se colocar como o fundador da escola, mas quando da pesquisa que resultou neste estudo, ao observa-se os documentos de criação dessa escola, ver-se que o missionário Tonini assinou os primeiros documentos na qualidade de fundador da mesma. $\mathrm{Na}$ época da fundação, a escola atendia ao público do antigo ginásio, ou seja, o público do quinto ao nono ano que atualmente se denomina de segunda fase do ensino fundamental.

$\mathrm{Na}$ época, a prefeitura contribuía com a manutenção da unidade escolar, segundo Tonini, logo não conseguiu manter o apoio e a escola foi entregue totalmente aos orionitas. $\mathrm{O}$ missionário registrou que a escola despontava de prestígio tanto na capital de Goiás como no norte do país, certamente como experiência bem-sucedida de uma escola ginasial administrada por missionários católicos.

Mas por que esse interesse dos missionários orionitas em atuar na educação, sobretudo nas primeiras séries da formação inicial? Sobre essa preocupação da Igreja com a primeira fase da educação, José Mateus do Nascimento reflete:

A Igreja ao atender à criança/jovem por intermédio da educação, trazia a intenção oculta de se evitar o adulto desajustado. No prefácio à obra "Infância no Sótão", Arroyo revela que os projetos pedagógicos dessas instituições como a Igreja, objetivavam construir, desde a infância, o adulto desejado: ordeiro, trabalhador, civilizado, capaz de ser integrado à ordem social (NASCIMENTO, 2006, p.69-70). 


\section{Revista de História e}

Historiografia da Educação

Como se pode observar a partir de Nascimento, verifica-se que a atuação da Igreja Católica no campo da educação nem sempre pode ser analisada somente pelo prisma da caridade e da assistência social. Nascimento abre a possibilidade de uma nova leitura, a que busca compreender nessa estratégia da Igreja de atuar na educação, outro objetivo e sentido, o que ele chama de esforço/estratégia da Igreja para a construção do "adulto desejado", civilizado, que venha integrar a sociedade sem ocasionar maiores problemas à mesma.

Terá sido essa a estratégia que norteou também, as ações dos missionários orionitas no campo da educação na região objeto deste estudo? Acredita-se que também. Sobre a fundação da segunda unidade escolar orionita, a Escola Sagrado Coração de Jesus na cidade de Araguaína, foi criada pelo missionário orionita Pacífico Mecozzi no ano de 1955. Na época da fundação, foi uma escola de ensino primário, ou seja, atendia do primeiro ao quarto ano do que atualmente se denomina de primeira fase do ensino fundamental. Sempre funcionou ao lado da Igreja que leva o mesmo nome, na região central de Araguaína ${ }^{6}$.

Assim como a primeira escola fundada pelos missionários orionitas, essa segunda também atendia ao público infantil. Sobre a atuação da Igreja Católica na seara do ensino infantil brasileiro, Nascimento reflete:

Alcançar primeiro a infância estava em consonância com a Doutrina Social da Igreja que exprimira a preocupação em atender a necessidade de educação do povo pobre,

\footnotetext{
${ }^{6}$ Sobre essa escola orionita, assim como o Ginásio Dom Orione de Tocantinópolis, é uma das mais antigas da região. Também desde a fundação funciona como uma escola sem fins lucrativos, de natureza pública. Assim como o estabelecimento de Tocantinópolis, a Escola Sagrado Coração de Jesus é mantida por intermédio de um convênio com o governo do Tocantins, que custeia as despesas com seus servidores. Da época de sua fundação até décadas recentes foi considerada a principal escola de ensino fundamental da cidade. Já chegou a contar com 600 alunos matriculados.
} 


\section{Revista de História e}

Historiografia da Educação

preparando-o para o futuro. Assim, as crianças representavam um segmento importante na construção desse futuro, por isso incomodavam quando mendigavam pelas ruas. Era uma realidade que deveria ser imediatamente contornada, não podendo se perpetuar, pois um dia se tornariam adultos. E que pessoas adultas seriam? (NASCIMENTO, 2006, p.69).

Nascimento observa a preocupação da Igreja em atuar na educação a partir da infância. Segundo ele, a Igreja tinha o discurso de preocupação com a educação das crianças desde a infância por causa do futuro das mesmas. Era a preocupação em evitar que as mesmas não terminassem indo para as ruas, para isso a preocupação era evitar que na fase adulta elas representassem poucos problemas para a sociedade.

Já a terceira unidade escolar fundada pelos missionários orionitas, foi o Ginásio Santa Cruz, criado por Remígio Corazza em Araguaína, sempre foi uma escola privada. Sobre a fundação dessa unidade escolar, o próprio Corazza registrou:

Aquele homem bom e simples, prefeito de Araguaína, cidade que crescia com rapidez e desordenadamente, com alto índice de jovens sem futuro, repetidas vezes insistia comigo a mesma cantilena: Padre, vamos criar um Ginásio. A questão não é querer, Sr. prefeito, nem também é pessoal. O prefeito não se deu por vencido e continuou insistindo. Depois de negociações, perguntou-se: Que nome será dado ao Ginásio? Dom Orione? Não, excelência. Qual o santo de hoje? Dia da Santa Cruz, respondi. Que tal chamar-se Ginásio Santa Cruz? Ótimo. E fomos logo entrando nos pormenores. Os recursos pedagógicos e didáticos eram precários. Faltavam professores habilitados. O que havia de sobra era alunos. Não desanimamos. A primeira série começou com sessenta e dois alunos, acomodados num prédio velho com três salas abandonadas e quase caindo. Estávamos em 1964 (CORAZZA, 2000, pp.66-67).

Como registrou Corazza, de um diálogo entre ele o prefeito de Araguaína na época, surgiu a ideia da criação da escola orionita na 


\section{Revista de História e}

\section{Historiografia da Educação}

cidade. Interessante observar que, como ocorrido com a escola de Tocantinópolis, a iniciativa surgiu por parte do poder público. $\mathrm{Na}$ verdade, embora fosse projeto dos orionitas atuarem na educação, ao que parece, esperavam eles o momento certo da abertura de cada escola.

Como no caso de Tocantinópolis e Araguaína, a iniciativa foi dos prefeitos locais, mas logo os projetos foram abraçados pelos orionitas, até a implantação efetiva das escolas. Sobre o Ginásio Santa Cruz na cidade de Araguaína, apesar de ter sido criado em 1963, ou seja, na segunda década de atuação dos missionários orionitas na região, onze anos após a chegada dos primeiros missionários e oito anos após a fundação da primeira escola orionita de Araguaína, o Santa Cruz sempre recebeu toda a atenção da congregação orionita. Tanto a atenção no que se refere à estrutura física e investimentos, quanto ao marketing. Ao que parece, essa escola sempre foi a "menina dos olhos" dos missionários orionitas na região7.

Pode-se inferir, sem sombra de dúvidas, que a elite da cidade de Araguaína passou pelas salas de aula e corredores dessa última escola, desde professores da cidade, médicos, engenheiros, advogados, juízes e até alguns que se tornaram prefeitos. Daí acredita-se, seja essa uma das explicações para tamanho prestígio dessa escola orionita em Araguaína.

Quem sabe, essa projeção do atual Colégio Santa Cruz parece ter "ofuscada" as outras escolas orionitas, principalmente as conveniadas com o poder público. Pouco ou quase nenhuma importância é dada às

\footnotetext{
7 Essa escola, na época de sua fundação chamada de Ginásio Santa Cruz, foi a única bem estruturada da cidade de Araguaína na década de 1960, passou por grandes transformações ao longo do tempo. Anos depois, passou a atuar além do ensino fundamental, também no ensino médio, quando passou a chamar-se Colégio Santa Cruz. Hoje é uma instituição de ensino totalmente particular e dispõe da maior estrutura educacional e física da cidade e região. Reconhecido como um dos melhores colégios do Tocantins. Para mais informações sobre essa instituição de ensino de propriedade da congregação orionita.
} 


\section{Revista de História e}

\section{Historiografia da Educação}

outras, nem sequer as mesmas constam nos sites oficiais da congregação. Nesse sentido, em todas as sedes da missão orionita na região foram criadas as escolas da congregação, absolutamente todas as sedes contavam com sua unidade de ensino.

Neste estudo, foram destacadas as três últimas, primeiro, pela ordem de antiguidade e, segundo, pela importância que é dada a elas pela congregação orionita, com destaque é claro, para o Ginásio Santa Cruz, tempos depois transformado em Colégio Santa Cruz, em Araguaína $^{8}$. Assim se constituiu algumas obras orionitas na área da educação no antigo extremo norte goiano. Sobre a atuação dos missionários orionitas no campo da educação na região, Vera Caixeta reflete:

Construir uma rede de escolas paroquiais ia ao encontro das recomendações da Igreja que, através do sínodo diocesano de Campinas, realizado em 1938, orientava aos bispos e padres a abrir escolas católicas, farmácias e hospitais. Contudo, tais ações sociais e filantrópicas, segundo Luís Roberto Benedetti, eram compreendidas como instrumento de competição contra outras religiões, ou seja, estavam a serviço do proselitismo. De qualquer forma, as instruções de Dom Alano aos missionários "orionitas" estavam articuladas às

\footnotetext{
8 Durante a pesquisa que resultou neste estudo, uma questão surgiu: o que era, afinal de contas, a educação orionita? Seria o catecismo o único conteúdo administrado nas escolas? O que, afinal de contas, era ensinado nas escolas orionitas? Ao analisar as narrativas dos missionários e alguns documentos nas principais escolas orionitas da região, percebe-se que, de fato, não existe um manual que regule e normatize a educação orionita, não existe sequer um esquema pedagógico ou um documento escrito que aborde o que seja essa educação orionita. Diante dessa constatação e, tendo em vista os orionitas atuarem na região fundando, mantendo escolas e visitando as já existentes, inclusive as públicas não católicas, persistiu a inquietação. Daí chega-se à seguinte conclusão para essa ausência de um documento escrito sobre a educação e pedagogia orionita: é justamente nessa ausência de uma orientação escrita, na ausência de uma "normativa" que venha a orientar o que seja a educação orionita, que eles atuam, educam e pregam o que eles acreditam, ou seja, uma educação de matriz católica de carisma orionita.
} 


\section{Revista de História e}

Historiografia da Educação

orientações da Igreja no Brasil e dentro da "especialidade" daquela Congregação (CAIXETA, 2014, p.172).

Conforme refletiu Caixeta, as ações dos orionitas na área da educação estavam em conformidade com as diretrizes da Igreja Católica no Brasil de atenção por parte dessas congregações religiosas nessas áreas. Segundo, essas ações foram vistas como instrumentos de competição do catolicismo com outras religiões. Entende-se que a participação dos orionitas na educação na região, teve objetivo certo: demarcar um território e estabelecer a ética católica na região, por fim, ajudar a estruturar o catolicismo no espaço e contexto histórico analisado neste estudo.

Ainda sobre o ensino católico que se acredita, foi o que se colocou em prática com vistas a essa estruturação do catolicismo, os orionitas nem sequer esconderam que a religião católica era a que estava sendo ensinada nas escolas, basta observar o que Tonini registrou:

O primeiro ponto abordado foi o ensinamento do catecismo nas paróquias, nas capelas, nas escolas privadas e públicas. No Brasil existe a separação entre a Igreja e o Estado, porém a Constituição contempla a plena liberdade de culto e de ensinamento religioso nas escolas. "Será ensinada a religião da maioria a pedido dos pais dos alunos sem, porém aviltar a minoria”. Este artigo abre as portas de todas as escolas ao sacerdote (TONINI, 1996, p.182).

Observa-se, novamente, a preocupação dos missionários orionitas com a administração nas escolas da região do ensino católico. Ele inclusive destacou que esse ensino deveria ser aplicado em todas as escolas e invocou a constituição do país que, para ele, embora separasse a Igreja do Estado, abria a possibilidade do ensino da religião da maioria dos alunos matriculados.

Interessante observar que Tonini, ao que parece, estava versado nas leis do país, talvez de forma que pudesse exigir o que ele entendia ser seu direito, direito que se imagina, naquele momento, ele invocava 


\section{Revista de História e}

Historiografia da Educação

para ensinar o que ele acreditava: a ética católica romana nas escolas da região. De fato ensinou, e com um detalhe: se nas escolas não católicas os missionários orionitas entraram, imagina-se o que eles não "pregavam" e difundiam nas escolas de suas propriedades?

Sobre essa prática de Tonini, de levar o catolicismo a todas as escolas, Caixeta reflete: "A luta do padre Tonini (...), não foi apenas para reduzir as escolas protestantes "aos filhos da heresia", como ele havia dito. Mas sim, para reduzir o tamanho daquelas igrejas, foi, então, uma disputa por fiéis" (CAIXETA, 2014, p.174).

A partir da reflexão de Caixeta, observa-se que os missionários orionitas, entre outras coisas, travaram uma disputa que foi muito além do campo da educação na região. Foi uma disputa por "almas" para o catolicismo. Foi uma disputa de igrejas, de modelos de religião, ou seja, uma disputa por espaço no campo religioso. Daí interpreta-se de que estava em curso um processo estruturante do catolicismo naquele momento. O espaço no momento era a escola, a educação. E esse espaço deveria ser delimitado, para que, segundo Tonini e seus missionários, não restasse espaço para os seus "inimigos", os protestantes.

Os missionários orionitas chegaram, inclusive, a proibir os católicos de matricularem seus filhos em escolas que não fossem as escolas orionitas ou aquelas que eles não pudessem ter acesso, conforme se pode observar quando Tonini registrou: "Onde havia escolas estatais, municipais ou paroquiais, os católicos não deviam matricular seus filhos em escolas acatólicas. Os infratores seriam considerados pecadores públicos" (TONINI, 1996, p.184).

Observa-se o que pode ser considerado o ponto alto do que os orionitas consideravam para a educação do antigo extremo norte goiano. Ponto alto no sentido de que eles explicitaram de forma clara o que estava em jogo naquele momento. Ao proibirem os católicos de estudarem em escolas que não fossem orionitas, os pais dos alunos 


\section{Revista de História e}

Historiografia da Educașão

seriam punidos, considerados "infratores" e seriam ainda, expostos como pecadores públicos ante a igreja.

Sobre a disputa entre os missionários orionitas e os protestantes considerados por eles como inimigos, tendo a escola como espaço, Vera Caixeta ainda reflete:

Os pais insubordinados seriam considerados pecadores públicos e como tal seriam excluídos dos sacramentos e se morressem ser-lhe-ia negado o funeral religioso. Para o missionário católico, o papel da escola paroquial estava além da transmissão cultural e da socialização das crianças e jovens. Tonini leu a carta ao final da missa e antes da benção final. Segundo ele, em se tratando de religião e de educação, os católicos não poderiam ter nada em comum com os protestantes (CAIXETA, 2014, p.173).

O que estava em “jogo” era a implantação, manutenção e em suma, a estruturação do catolicismo na região, por intermédio da educação. A educação orionita nesse caso foi o caminho a ser seguido, colocado em prática, mas estavam os seus projetos muito além de um projeto educacional, mas de caráter religioso, ético e moral, tendo o catolicismo como o norteador de todo o processo histórico então em curso.

Pode-se inferir que foi na verdade, um tipo de educação totalmente voltada para o aspecto da fé, basta verificar esse registro de Tonini:

Para construir um grande edifício são necessárias bases profundas. Pe. Tonini recorreu às professoras locais. Reuniuas e concretizou um curso especial de catecismo só para elas. Deveriam representar o grupo das catequistas especializadas para injetar as verdades divinas nos tecidos profundos de seus alunos. A iniciativa era acertada; deveria alargar-se, aprofundar-se, estender-se (TONINI, 1996, p.73).

Como exposto por Tonini, foi necessário construir o "edifício" e que para tal, foram necessárias "bases profundas". O que Tonini quis 


\section{Revista de História e}

\section{Historiografia da Educação}

dizer? Construir o edifício foi o mesmo que construir o catolicismo como religião majoritária na região, hegemônica entre o povo, e a necessidade para isso de "bases profundas" foi a educação, base para a formação do caráter, da moral, da ética e da cultura. Daí acredita-se que a educação foi vista como a ponte, o meio, o caminho que conduziria à formação do edifício: o edifício católico do extremo norte goiano.

Sobre a necessidade apontada por Tonini em edificar o catolicismo a partir da base, ou seja, a partir da educação, Vera Caixeta ainda reflete:

Na verdade, Tonini estava cobrando fidelidade do rebanho a um só pastor e isso incluía enviar os filhos para a escola católica. Porém, para que sua mensagem fosse aceita e acatada primeiro ele tratou de construir o prédio religioso, a escola paroquial e o posto médico. Além disso, ele também se preocupou em organizar várias associações religiosas e fazer um trabalho de catequese de crianças e de adultos. Enfim, foi necessário um amplo investimento, por parte do missionário, para transformar todos em fiéis católicos (CAIXETA, 2014, p.173).

Observa-se que as ações na esfera da educação, colocadas em prática pelos missionários orionitas no antigo extremo norte goiano na década de 1950 e 1960 tiveram como objetivo final a edificação do catolicismo na região ${ }^{9}$. As ações orionitas naquele momento vistas sob

\footnotetext{
9 Importante observar que nas décadas seguintes ao recorte deste estudo, ou seja, a partir dos anos 1970 em diante, a congregação orionita continuou investindo na área da educação em Araguaína, abriu ainda outra unidade de ensino, a Escola Paroquial Luis Augusto, também mantida através de um convênio com o governo do Tocantins e, mais recentemente, no início dos anos 2000, foi inaugurado um dos maiores investimentos da congregação orionita na área da educação: a Faculdade Católica Dom Orione. Essa faculdade orionita é totalmente particular, atualmente oferece vários cursos superiores como: Direito, Administração, Psicologia. Junto com o atual Colégio Santa Cruz e as duas escolas paroquiais, faz da cidade de Araguaína, polo e referência na área da educação para a congregação orionita em todo mundo.
} 


\section{Revista de Fistoria e}

Historiografia da Educașão

o prisma da educação foram os elementos que levaram os missionários orionitas a estruturarem a Igreja Católica no antigo extremo norte de Goiás, atual Tocantins.

\section{Considerações finais}

Este estudo teve como objetivo refletir a atuação dos missionários católicos orionitas, no campo da educação, no antigo extremo norte de Goiás, atual Tocantins, na década de 1950 e 1960. Eles atuaram com destacado êxito no espaço, no que se refere à implantação de escolas, as primeiras da região. Foram implantadas unidades escolares em todas as sedes da missão. Viu-se também que os orionitas utilizaram a educação como instrumento de catolicização do antigo extremo norte goiano, frente às igrejas e escolas protestantes.

Quando os missionários orionitas estabeleceram-se lá, início da década de 1950 havia muito poucas escolas instaladas na região, mais precisamente, duas, uma em Tocantinópolis, outra em Filadélfia. A partir desse quadro, começaram a instalar outras escolas pelas sedes da missão orionita. Importante observar que a estratégia da Igreja de atuar na esfera da educação não é incomum. A Igreja sempre utilizou desse método: a educação associada à evangelização.

A partir dessa constatação, pode-se questionar, então, se o interesse dos missionários orionitas não foi exclusivamente o de educar, mas imprimir uma presença religiosa? Segundo nossa compreensão, no caso do extremo norte goiano com os orionitas, acredita-se que houve sim, o interesse em alfabetizar, intelectualizar, enfim, educar, mas ao que parece, sob as bases da doutrina católica. Foi como eles procederam.

Viu-se também, que a princípio, os missionários orionitas diagnosticaram, no início dos anos 1950 a situação da região, chegaram 


\section{Revista de História e}

\section{Historiografia da Educação}

à conclusão de que no que se referia ao campo educacional, a região era um "campo descoberto". Então eles agiram: formaram professores em todas as sedes da missão com o objetivo de visitar as escolas já existentes à época. Vendo que essa estratégia de formar professores já não funcionava à altura do desafio, seguiram, a partir de 1952, o conselho do então bispo, começaram a fundar suas próprias escolas paroquiais: surgiram as escolas orionitas.

Dentre essas escolas, neste estudo, abordaram-se as três principais: em 1954 o Ginásio do Norte Goiano, atualmente Colégio Dom Orione em Tocantinópolis, em 1955 a Escola Sagrado Coração de Jesus, atualmente Escola Paroquial Sagrado Coração de Jesus em Araguaína e em 1963, também em Araguaína, o Ginásio Santa Cruz, atualmente, Colégio Santa Cruz. Para além dessas três, todas as sedes da missão orionita também tiveram suas escolas paroquiais, nas cidades de Filadélfia, Babaçulândia, Ananás, Araguatins, Itaguatins e Xambioá.

Finalmente, os missionários orionitas estabeleceram-se na região e por intermédio de ações educacionais, como fundação de escolas e visitas a outras, catolicizaram a região para, em última instância, enfrentar quem eles consideraram seus inimigos: os protestantes. Como sugeriu o título deste estudo, os orionitas educaram ao modo deles, os sertanejos da região: ao usar a escola e a educação como instrumento de catolicização do antigo extremo norte goiano nas décadas de 1950 e 1960. 


\section{Referências}

AZZI, Riolando. A Igreja Católica na Formação da Sociedade Brasileira. Aparecida: Editora Santuário, 2008. CAIXETA, Vera Lúcia. Médicos, Frades e Intelectuais: Leituras Sobre os Sertões do Brasil Central (1882-1935). Curitiba, Editora CRV, 2014. CORREIA, Aldenora. Boa Vista do Padre João: Tocantinópolis, Goiás. S/Editora, S/Data.

LELLI, Cesare. Voz do Norte, pp. 34-36, Tocantinópolis: S/Ed, 1980. NASCIMENTO, José Mateus do. Vinde a Mim os Pequeninos Práticas Educativas da Diocese de Natal (1945-1955). IN: PAIVA, Marlúcia Menezes de. (Org.). Igreja Católica e Suas Práticas Culturais. Brasília: Líber Livro Editora, 2006.

PALACIN, Luis G. O Coronelismo no Extremo Norte de Goiás: o padre João e as três revoluções de Boa Vista. São Paulo: Loyola, 1990.

PATTARELLO, Giovani. Perfil de Dom Orione. São Paulo: S/Editora, 1985.

TONINI, Quinto. Entre Diamantes e Cristais: Cenas Vividas Pelos Missionários de Dom Orione nas Matas do Norte de Goiás. Fortaleza: Expressão, 1996.

WOODS, Thomas. Como a Igreja Católica Construiu a Civilização Ocidental. São Paulo: Editora Quadrante, 2008. 